\title{
Erratum to: Lenalidomide in patients with cisplatin-refractory and multiply relapsed germ cell tumors
}

\author{
Karin Oechsle • Carsten Bokemeyer • \\ Friedemann Honecker
}

Published online: 27 October 2009

(C) Springer-Verlag 2009

\section{Erratum to: J Cancer Res Clin Oncol DOI 10.1007/s00432-009-0677-2}

The last sentence of the abstract was incorrect.

The correct sentence is "Lenalidomide was well tolerated but did not show efficacy in heavily pretreated patients with cisplatin-refractory and multiply relapsed germ cell tumors."

The online version of the original article can be found under doi: 10.1007/s00432-009-0677-2.

K. Oechsle $(\varangle) \cdot$ C. Bokemeyer $\cdot$ F. Honecker

Departments of Oncology, Hematology,

Bone Marrow Transplantation and Pneumology,

University Medical Center Eppendorf, Martinistr. 52,

20246 Hamburg, Germany

e-mail: k.oechsle@uke.hamburg.de 